\title{
Physiology and quality of 'Tahiti' acid lime coated with nanocellulose-based nanocomposites
}

\author{
Jessica Cristina Urbanski LAURETH ${ }^{1}$, Alice Jacobus de MORAES ${ }^{1}$, Daiane Luckmann Balbinotti de FRANÇA ${ }^{1}$, \\ Wilson Pires FLAUZINO NETO², Gilberto Costa BRAGA ${ }^{1 \star}$
}

\begin{abstract}
The aim of this study was to evaluate the physiological response and quality of the 'Tahiti' acid lime coated with carboxymethylcellulose $(\mathrm{N}-\mathrm{CMC})$, pectin (N-PEC) and starch (N-ST) nanocomposites based on cellulose nanocrystals (NC). Respiratory rate, ethylene production, loss of fresh weight, total chlorophyll and fruit firmness were evaluated during 9 days of storage. At the end of storage, only fruits coated with N-CMC and N-PEC exhibited significantly lower ethylene yield $\left(0.92\right.$ and $0.98 \mu \mathrm{C} \mathrm{C}_{2} \mathrm{H}_{4} \mathrm{~kg}^{-1} \mathrm{~h}^{-1}$, respectively) than fruits coated with CMC and PEC (1.6 and $2.02 \mu \mathrm{g} \mathrm{C}_{2} \mathrm{H}_{4} \mathrm{~kg}^{-1} \mathrm{~h}^{-1}$, respectively). On the $3 \mathrm{rd}$ day of storage, fruits coated with N-PEC showed a respiratory rate $\left(12.01 \mathrm{mg} \mathrm{CO}_{2} \mathrm{~kg}^{-1} \mathrm{~h}^{-1}\right)$ similar to the fruits of the control $\left(13.52 \mathrm{mg} \mathrm{CO}_{2} \mathrm{~kg}^{-1} \mathrm{~h}^{-1}\right)$, but it was significantly lower than the fruits coated with PEC $\left(14.93 \mathrm{mg} \mathrm{CO}_{2} \mathrm{~kg}^{-1} \mathrm{~h}^{-1}\right)$. Only fruits coated with N-PEC showed significantly lower fresh weight losses than the control fruits. Fruits coated with N-PEC had chlorophyll retention levels (18.95 $\left.\mathrm{mg} \mathrm{g}^{-1}\right)$ higher than fruits with PEC (13.25 $\left.\mathrm{mg} \mathrm{g}^{-1}\right)$. This work showed that the N-PEC nanocomposite, based on NC, was the coating that showed greater potential for preserving quality of the 'Tahiti' acid lime.
\end{abstract}

Keywords: Citrus latifolia; respiration; ethylene; fresh weight loss; chlorophyll; firmness.

Practical Application: The addition of nanocellulose in the pectin film forms a coating with better barrier properties for fruit preservation.

\section{Introduction}

The 'Tahiti' acid lime is a citrus fruit that has great worldwide popularity due to its acid taste, high nutritional value and easy availability, but after harvest it is prone to the rapid deterioration of physical, physiological and microbiological order. Studies have shown that the post-harvest quality of fruits can be prolonged by applying a thin layer of polymer coating on the peel (Yousuf et al., 2018), with the main purpose of delaying water loss and wrinkling, and to increase peel brightness. For commercialization, acid limes are usually coated with non-edible synthetic polymers, but actually the use of materials that are beneficial to health and the environment has been highly valued (Mditshwa et al., 2017). Therefore, the use of edible coatings has received a lot of attention because: (i) they are non-toxic and safe for food use; (ii) they are produced from renewable agricultural sources; and (iii) leads to a reduction in the use of synthetic packaging. However, its application has limitations due to its reduced mechanical and water vapor barrier properties (Cazón et al., 2017).

A recent technique, based on the addition of nanomaterials to form reinforced biopolymer nanocomposite coatings has been the focus of several investigations (Oun \& Rhim, 2016; Deng et al., 2017; Li et al., 2017; Xin et al., 2017). In fact, nanocomposite coatings generally have better mechanical, thermal, optical and physicochemical properties compared to pure polymer coatings (Ma et al., 2017). Among the known nanomaterials, cellulose nanocrystals have been used to improve the properties of biopolymers (Oun \& Rhim, 2016), since they have characteristics such as high crystallinity index and high resistance (Nagalakshmaiah et al., 2016). Cellulose nanocrystals are needle-shaped, have a size equal to or less than $100 \mathrm{~nm}$, have a large specific surface area, high modulus of elasticity and great aspect ratio, and the processes for their isolation are based on acid hydrolysis to break down the amorphous domains of the cellulosic fibers (Flauzino et al., 2016).

Fruit coatings are based on biopolymers of polysaccharides, proteins or lipids, or several composites, which are usually applied by immersion of the vegetable in the coating solution, forming a thin layer on its surface (Cazón et al., 2017). They function as a partial barrier to the passage of $\mathrm{O}_{2}, \mathrm{CO}_{2}$ and water vapor, retarding respiratory metabolism, physiological degradation and loss of fresh fruit weight (Yousuf et al., 2018). Among the coating polymers used in fruit, the starch polysaccharides (Jaramillo et al., 2016), pectin (Mannozzi et al., 2017) and carboxymethylcellulose (Chen et al., 2016) have been studied. Cassava starch is high availability, low cost, colorless, with no taste and good oxygen barrier, but it has a high capacity to absorb water (Jaramillo et al., 2016). Pectin can be obtained by aqueous extraction of edible vegetables, usually citrus or apples, and is available in high percentages in agro-industrial waste. In certain circumstances,

${ }^{1}$ Centro de Ciências Agrárias - CCA, Universidade Estadual do Oeste do Paraná - UNIOESTE, Marechal Cândido Rondon, PR, Brasil

${ }^{2}$ Instituto de Química, Universidade Federal de Uberlândia - UFU, Campus Santa Mônica, Uberlândia, MG, Brasil

*Corresponding author: gcb1506@gmail.com 
it forms gels and is therefore widely used as an additive in jellies, jams, marmalades and confectionery, with high potential for use as a fruit coating (Cazón et al., 2017). Carboxymethylcellulose is derived from cellulose and is used as a stabilizer additive in food, due to its non-toxicity, biocompatibility, biodegradability (Candido \& Gonçalves, 2016).

Many studies are based on the structural characteristics, bioactivity and trends of use of nanocomposites as fruit coatings (Pelissari et al., 2017; Tibolla et al., 2018), but their applicability as a coating, based on the physicochemical and physiological responses of fruits, needs to be better investigated. Theobjective of this study was to evaluate the influence of coatings carboxymethylcellulose, pectin and starch nanocomposites, based on cellulose nanocrystals, on the physiology and quality of stored 'Tahiti' acid lime.

\section{Materials and methods}

\subsection{Samples}

Samples of 'Tahiti' acid limes were obtained from an orchard located in Marechal Cândido Rondon, PR, Brazil. At harvest, fruits of green color, homogeneous size, without defects and healthy were selected. The fruits were washed with water, sanitized by immersion in sodium hypochlorite solution $\left(0.2 \mathrm{~mL} \mathrm{~L}^{-1}\right)$ for one minute (room temperature) and then air dried.

\subsection{Material and formation of coatings}

Three biopolymers were used in the coating formations: sodium carboxymethylcellulose (CMC) (viscosity: 2240 cp; Synth, SP, Brazil), citrus pectin (PEC) (esterification: 72\%; CP Kelko, SP, Brazil), and cassava starch (ST) (Fecularia Horizonte, PR, Brazil). CMC, PEC and ST film-forming solutions were prepared by dissolving the polymers in distilled water at concentrations of 1.0, 1.5 and $1.5 \%$ (respectively) under constant stirring. The CMC polymer was dissolved at room temperature $\left(25^{\circ} \mathrm{C}\right)$ for 2 hours, and PEC at $65^{\circ} \mathrm{C}$ for 40 minutes. ST was dissolved at $70{ }^{\circ} \mathrm{C}$ until its gelatinization. In each film-forming solution $1.0 \%(\mathrm{~m} / \mathrm{v})$ glycerol (Tec-Lab, Indaiatuba, SP, Brazil) was added as plasticizer. The polymer concentrations were determined through preliminary tests, based on the best fruit weight loss results.

Nanocomposite coatings were prepared by the addition of $8 \%(\mathrm{v} / \mathrm{v})$ of a solution of cellulose nanocrystals (NC) in CMC, $\mathrm{PEC}$ and ST polymer filmmaking solutions, forming the $\mathrm{N}-\mathrm{CMC}$, $\mathrm{N}$-PEC and N-ST nanocomposites. The NC were extracted from eucalyptus kraft pulp (Companhia Conpacel, Limeira, SP, Brazil) by acid hydrolysis at $60 \%$ sulfuric acid $(\mathrm{m} / \mathrm{m})$. The hydrolysis was carried out at $45^{\circ} \mathrm{C}$ for 50 minutes under constant stirring. For each gram of Kraft pulp, $20 \mathrm{~mL}$ of sulfuric acid was used. Immediately after hydrolysis, the suspension was diluted 10 -fold in water, and centrifuged twice for 8 minutes at $10000 \mathrm{rpm}$. The precipitate was then dialyzed with water until the neutral $\mathrm{pH}$ was reached. The suspension resulting from the dialysis procedure was sonified for 15 minutes, and then stored at $4{ }^{\circ} \mathrm{C}$ after adding a few drops of chloroform to avoid any bacterial growth, according to Flauzino et al. (2016).
The NC showed the following characteristics: crystallinity index $=89.1 \%$, length and diameter $=204 \pm 50 \mathrm{~nm}, 4.44 \pm 1.10 \mathrm{~nm}$, respectively, and aspect ratio $=47 \pm 14$. The crystallinity index was determined by the method of Segal et al. (1959) by X-ray diffractograms (Shimadzu LabX XRD-6000). Measurements of length, diameter and aspect ratio were performed by an AFM microscope (Shimadzu SPM-9600), selecting thirty-five nanocrystals for the measurements.

\subsection{Experimental}

The acid limes were immersed in nanocomposite (N-CMC, $\mathrm{N}-\mathrm{PEC}$ and N-ST) and pure polymer (CMC, PEC and ST) films for $1 \mathrm{~min}$ and then remained at room temperature $\left(25^{\circ} \mathrm{C}\right)$ for 3 hours until the films are completely dry. After being treated, the fruits were packed in trays of expanded polystyrene containing three fruits each, characterizing the experimental unit. They were then stored in an air-conditioned room at $23{ }^{\circ} \mathrm{C} \pm 2{ }^{\circ} \mathrm{C}$ and $75 \%$ UR for 9 days. Evaluations occurred at 3-day intervals. A control group of untreated fruits was stored under the same conditions.

\subsection{Respiratory activity and ethylene production}

Three fruits were placed in sealed plastic vials $(800 \mathrm{~mL})$ with silicone septum cap for gas sampling. $1.0 \mathrm{~mL}$ samples for respiratory rate $\left(\mathrm{mg} \mathrm{CO}_{2} \mathrm{~kg}^{-1} \mathrm{~h}^{-1}\right)$, and $2.5 \mathrm{~mL}$ for ethylene production ( $\mu \mathrm{g} \mathrm{C}_{2} \mathrm{H}_{4} \mathrm{~kg}^{-1} \mathrm{~h}^{-1}$ ), were collected from the headspace of the vials with a gasthight syringe (Hamilton). These collections occurred after one hour of the closure of the flasks for the determination of $\mathrm{CO}_{2}$, and after two hours for the determination of ethylene. The collected samples were injected in a gas chromatograph (Finnigan, 9001) calibrated for the column (Restek, phase RT-QPlot, 30m; $0.53 \mathrm{~mm}$ ), injector, detector and methanator temperatures of $80,150,250$ and $350{ }^{\circ} \mathrm{C}$ respectively. Nitrogen was used as the carrier gas.

\subsection{Physical and chemical quality}

The physical-chemical parameters evaluated were fresh weight loss, total chlorophyll and firmness. Fresh weight loss (\%) was determined by means of semi-analytical scale weighing, considering the initial weight of the fruits and the weights of each evaluation period. For Total chlorophyll, $1.0 \mathrm{~g}$ samples of the 'Tahiti' lime peel were ground and placed in $20 \mathrm{~mL}$ of $80 \%$ $(\mathrm{v} / \mathrm{v})$ acetone extracting solution. The extracts were rested in the dark under refrigeration at $4{ }^{\circ} \mathrm{C}$, and after 48 hours were centrifuged at $4000 . \mathrm{g}$ and $4{ }^{\circ} \mathrm{C}$. The supernatant was read in a spectrophotometer (Shimadzu, UV-1800, Japan) at $663 \mathrm{~nm}$ (chlorophyll a) and $645 \mathrm{~nm}$ (chlorophyll b) as described by Arnon (1949). The total chlorophyll content (TC) was expressed in $\mathrm{mg} \mathrm{g}^{-1}$ according to the following Equation 1:

\section{$C T: 8.0 x($ absorbance at $663 \mathrm{~nm})+20.2 \times($ absorbance at $645 \mathrm{~nm})(1)$}

Fruit firmness was measured with a digital texturometer (Brookfield, CT3, USA). The whole fruits were placed on a flat surface and their firmness was measured in the equatorial region. A stainless steel rod with a diameter of $8 \mathrm{~mm}$ was used. The test 
speed was adjusted to $2 \mathrm{~mm} \mathrm{~s}^{-1}$, with a displacement depth of $10 \mathrm{~mm}$. The results were expressed in Newton $(\mathrm{N})$.

\subsection{Statistical analysis}

Based on the completely randomized design, the data were submitted to analysis of variance. For the variables whose $\mathrm{F}$ values were significant, the Tukey test was used to compare the means. The $95 \%$ confidence level was used. Three replicates were used in the respiration and ethylene production analyzes, and five replicates for weight loss, chlorophyll and firmness.

\section{Results and discussion}

\subsection{Production of ethylene and respiratory rate}

Ethylene production $\left(\mu \mathrm{g} \mathrm{C}_{2} \mathrm{H}_{4} \mathrm{~kg}^{-1} \mathrm{~h}^{-1}\right)$ and the respiratory rate $\left(\mathrm{mg} \mathrm{CO}_{2} \mathrm{~kg}^{-1} \mathrm{~h}^{-1}\right)$ of the 'Tahiti' acid lime (Figure 1) were measured on fruits coated with carboxymethylcellulose (N-CMC), pectin (N-PEC) and cassava starch (N-ST) nanocomposites (based on nanocellulose), and with their respective CMC, PEC and ST pure polymers. All fruits coated with nanocomposites or pure polymers exhibited significantly lower ethylene production $(\mathrm{p}<0.05)$ compared to control fruits (uncoated) on the 3rd day of storage (Figure 1a), suggesting that an initial physiological response due to the coatings tested led to lower ethylene production. However, on the 9th day fruits coated with N-CMC and N-PEC and N-ST showed significantly lower ethylene production (mean of $0.98 \mu \mathrm{g} \mathrm{C}_{2} \mathrm{H}_{4} \mathrm{~kg}^{-1} \mathrm{~h}^{-1}$ ) than the control fruits $\left(1.7 \mu \mathrm{g} \mathrm{C}_{2} \mathrm{H}_{4} \mathrm{~kg}^{-1} \mathrm{~h}^{-1}\right)$, but only those coated with $\mathrm{N}$-CMC and N-PEC exhibited significantly lower ethylene production ( 0.92 and $0.98 \mu \mathrm{g} \mathrm{C}_{2} \mathrm{H}_{4} \mathrm{~kg}^{-1} \mathrm{~h}^{-1}$, respectively) than the fruits coated with CMC and PEC pure polymers ( 1.6 and $2.02 \mu \mathrm{C} \mathrm{C}_{2} \mathrm{H}_{4} \mathrm{~kg}^{-1} \mathrm{~h}^{-1}$, respectively), indicating a possible modification of the physical barrier of these polymers due to NC reinforcement. Similar effect was found by Deng et al. (2017) when they tested nanocellulose-based chitosan coating in banana.

A reduction of ethylene production may occur primarily due to the physical barrier effect of the polymer coatings used in the fruits, but secondarily this decrease of ethylene can also be attributed to the decrease of $\mathrm{O}_{2}$ diffusion to the fruit and increase in intercellular $\mathrm{CO}_{2}$ concentrations by the same barrier effect. Consequently, these changes are able to reduce ethylene synthesis by inhibiting ACC oxidase (Taiz \& Zeiger, 2017). In fact, ethylene is a secondary metabolite, which is related to the aerobic metabolism of plant tissue. Saberi et al. (2018) also found lower rates of ethylene production in non-climacteric fruits coated with polysaccharide polymers.

The physiological responses induced by physical stresses imposed in the harvesting and post-harvest stages of fruits, such as transport or pre-storage handling, are well described in the literature (Dhital et al., 2017), and these stresses have been associated with an increase in ethylene production and respiration rate shortly after harvest (Mditshwa et al., 2017). This is a fact that may explain the increase of ethylene produced by the fruits of the control until the third day of evaluation (Figure 1a), as well as the increases in respiratory rates of the treated fruits and control in the same period (Figure 1b). In addition, the time elapsed between the harvest and the beginning of the assays
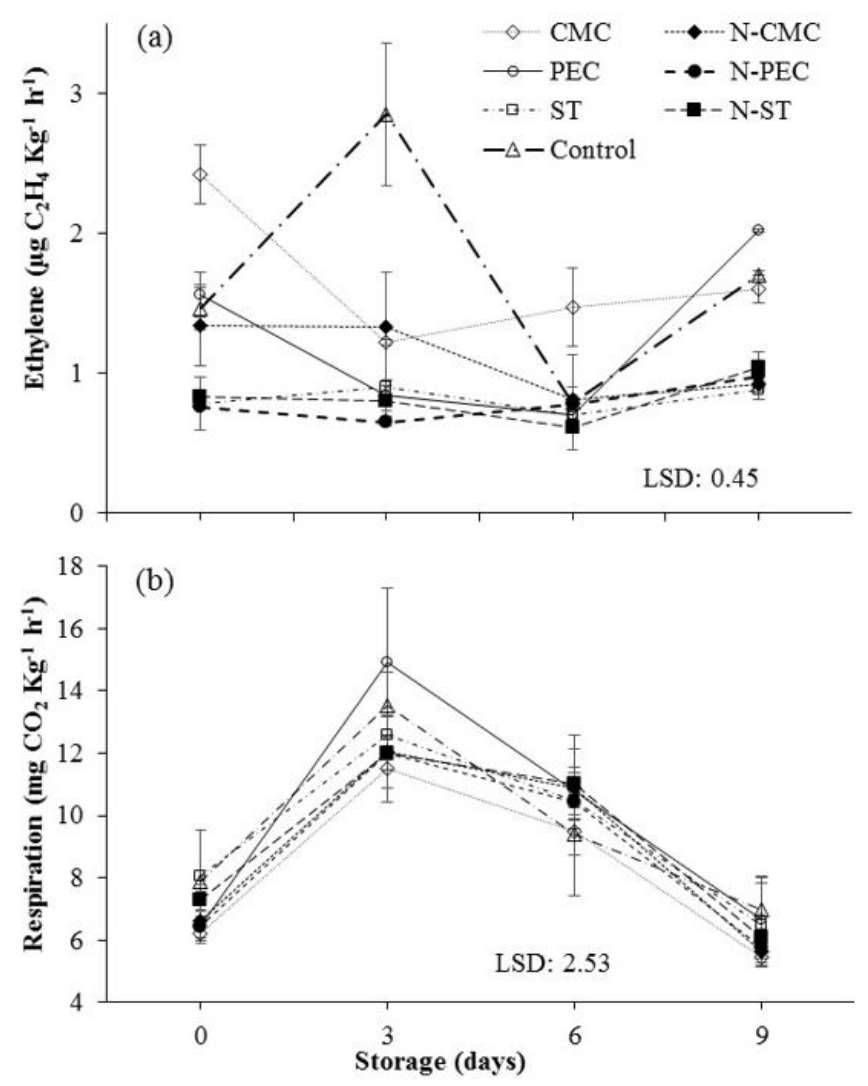

Figure 1. Production of ethylene (a) and respiratory rate (b) of the 'Tahiti' acid lime coated with carboxymethylcellulose (N-CMC), pectin (N-PEC) and starch (N-ST) nanocomposites, or with CMC, PEC and ST pure polymers. Control: uncoated fruit. Vertical bars indicate the standard deviation $(\mathrm{n}=3)$.

did not exceed six hours. If the physiological stresses that occur due to the harvest and transport stages lead to an increase in ethylene production, an increase in the respiratory rate of the fruits would be expected (Dhital et al., 2017). However, a positive association between ethylene and respiratory rate was observed only for the control (Figures $1 \mathrm{a}$ and $1 \mathrm{~b}$ ).

Although all fruits evaluated had respiratory rate increases up to the 3rd day of storage (Figure $1 \mathrm{~b}$ ), the respiratory rates of the fruit coated with $\mathrm{N}-\mathrm{CMC}$ and $\mathrm{N}-\mathrm{ST}$ nanocomposites (12.02 and $12.01 \mathrm{mg} \mathrm{CO}_{2} \mathrm{~kg}^{-1} \mathrm{~h}^{-1}$, respectively) and with their respective CMC and ST pure polymers (11.49 and $12.59 \mathrm{mg} \mathrm{CO}_{2} \mathrm{~kg}^{-1} \mathrm{~h}^{-1}$, respectively), did not show significant differences $(\mathrm{p}<0.05)$ and were statistically similar to the control ( $\left.13.52 \mathrm{mg} \mathrm{CO}_{2} \mathrm{~kg}^{-1} \mathrm{~h}^{-1}\right)$, suggesting that $\mathrm{NC}$ reinforcement did not contribute to improve the $\mathrm{O}_{2}$ barrier property of N-CMC and N-ST coatings. On the other hand, fruits coated with N-PEC showed a respiratory rate (12.01 mg CO $\mathrm{kg}^{-1} \mathrm{~h}^{-1}$ ) also statistically similar to the fruits of the control, but it was significantly lower than the fruits coated with PEC (14.93 mg CO $\mathrm{kg}^{-1} \mathrm{~h}^{-1}$ ), suggesting that the N-PEC nanocomposite was able to form an $\mathrm{O}_{2}$ diffusion barrier more efficient than its pure PEC polymer. Nanocomposites reinforced with high level of crystallinity, higher than $60 \%$, can form coatings capable of guaranteeing low levels of $\mathrm{O}_{2}$ permeability (Oun \& Rhim, 2016). This effect has been attributed to the formation 
of a rigid linked-hydrogen network (Flauzino et al., 2016), which seems to have occurred for the coating of the N-PEC nanocomposite, since the crystallinity index of the NCs used in N-PEC was $89.1 \%$.

After the third day of storage, the respiratory rates of treated and control fruits decreased significantly until the end of storage (Figure $1 \mathrm{~b}$ ). These decreases are not related to the treatments applied, and probably occurred due to a reduction of the physiological stress of the fruits, which responded physiologically showing low levels of respiratory intensity, characteristic of the species (Opio et al., 2017).

\subsection{Fresh weight loss, firmness and chlorophyll}

$\mathrm{N}-\mathrm{CMC}, \mathrm{N}-\mathrm{PEC}$ and N-ST coated fruits and CMC, PEC and ST pure polymers exhibited fresh weight loss with non-significant changes $(p<0.05)$ throughout the storage period (Figure 2a). However, in the 6th and 9th days only N-PEC coated fruits showed losses of fresh weight (3.24\% and $4.33 \%$, respectively) significantly lower than the losses of fruits of the control (4.38 and 5.68\%, respectively). This suggests that the NC-based reinforcement was able to form a pectin nanocomposite (N-PEC) with better water vapor barrier property compared to the PEC pure polymer. Polymeric coatings films with efficient water vapor barriers are able to reduce the movement of water vapor by stomata of fruit peels, and this reduces their transpiration while maintaining the turgescence of cell walls (Nawab et al., 2017). This partial physical barrier mechanism of the coating leads to a reduction of water diffusion through the fruit stomata. This barrier mechanism of coating films is important for fruit conservation since high weight loss (above 10\%) induces water stress, increases respiratory activity and accelerates senescence. Gardesh et al. (2016) also found similar results with retention of fresh weight in fruits treated with films reinforced with nanoparticles.

All coated fruits showed statistically similar $(\mathrm{p}<0.05)$ chlorophyll contents to the control until the 3rd day of storage (Figure 2b), indicating that initial increases in respiratory rate exhibited by fruits (Figure 1b) had no association with chlorophyllase activity or with synthesis of other pigments until this period. However, on the 6th day of storage N-PEC was the only nanocomposite that significantly influenced a higher level of chlorophyll retention $\left(18.95 \mathrm{mg} \mathrm{g}^{-1}\right)$ when compared to its respective PEC pure polymer $\left(13.25 \mathrm{mg} \mathrm{g}^{-1}\right)$. This suggests that the N-PEC nanocomposite was able to reduce respiratory metabolism related to the green color loss of the 'Tahiti' acid lime, most likely because this coating reduced the diffusion of $\mathrm{O}_{2}$ to the fruit, which may have led to a decrease in gene expression for fruit chlorophyllase activity. The maintenance of the green color of the 'Tahiti' acid lime peel, besides valuing the fruit in the market, is important for consumer acceptability (Kaewsuksaeng et al., 2015).

Non-significant differences $(\mathrm{p}<0.05)$ to the fruits firmness results were found for all coatings (Figure $2 c$ ) throughout the storage period. However, on the 6 th and 9 th days all the coatings tested were able to significantly delay the loss of firmness of the fruits, which presented higher values (mean values of $16.8 \mathrm{~N}$ and $15.41 \mathrm{~N}$, respectively) than the control $(11,49 \mathrm{~N}$ and $10.67 \mathrm{~N}$,
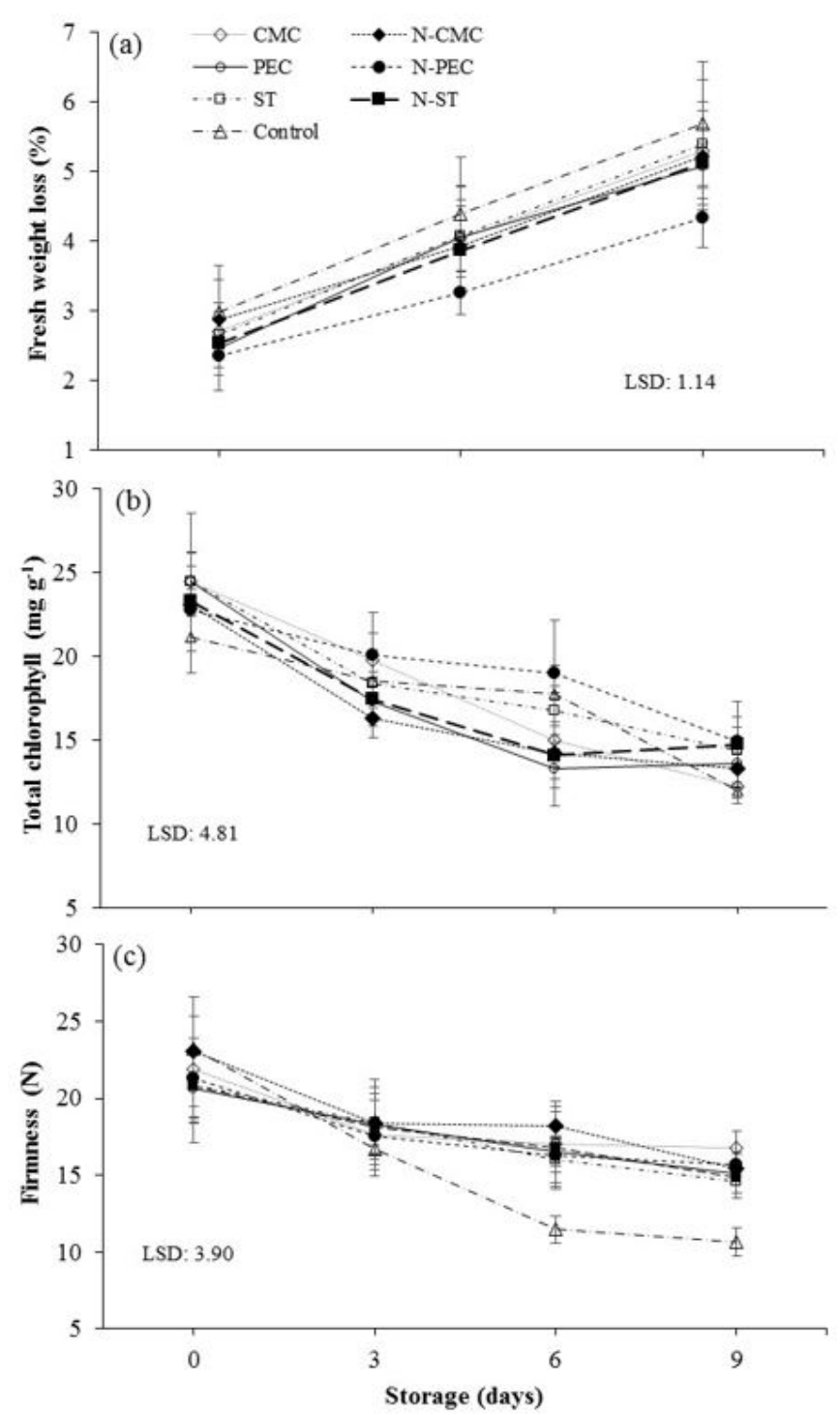

Figure 2. Loss of fresh weight (a), total chlorophyll (b) and firmness (c) of the 'Tahiti' acid lime coated with carboxymethylcellulose (N-CMC), pectin (N-PEC) and starch (N-ST) nanocomposites, or with CMC, PEC and ST pure polymers. Control: uncoated fruit. Vertical bars indicate standard deviation of the means $(n=5)$.

respectively). Although only the N-PEC coating has been able to promote a significant retention of fresh weight of the 'Tahiti' lime (Figure 2a), it is more likely that the retention of firmness, exhibited by all types of coatings, is more related to retention of fresh weight than the inhibition of respiratory activity caused by the gas barrier effect $\left(\mathrm{O}_{2}\right.$ and $\left.\mathrm{CO}_{2}\right)$. In fact, no association between respiratory rate (Figure 1a) and firmness was observed in this study, suggesting that the water vapor barrier property of the coatings had a positive effect on the maintenance of fruit firmness. Arnon et al. (2015) found firmness retention in mandarins coated with CMC, and associated this positive effect with the lower loss of fresh weight caused by this coating polymer.

The effect of the coatings on the firmness retention of fruits has a direct relation with its ability to control the loss of 
fresh weight (Khorram et al., 2017), or to inhibit respiratory metabolism related to the expression of enzyme activities, mainly pectinmetylesterase and polygalacturonase. These enzymes are responsible for the depolymerization of the chain of pectic substances in the cell wall, and protopectin degradation of the middle lamella and the primary cell wall (Dave et al., 2017). In fact, an internal gaseous modification of the fruit caused by coatings has been associated with the inhibition of the activity of the enzymes responsible for fruit softening (Li et al., 2017).

\section{Conclusions}

The pectin nanocomposite was the most efficient in inhibiting $\mathrm{CO}_{2}$ diffusion than the pectin pure polymer. The pectin nanocomposite coating was the only one able to reduce the fresh weight loss of the fruits and was more efficient in the retention of chlorophyll than the pectin pure polymer. This work showed that the addition of nanocellulose in the pectin film forms a coating with better barrier properties and consequently it adds more preservation of 'Tahiti' acid lime post-harvest quality, which is advantageous for commercialization.

\section{Acknowledgements}

The authors thank CAPES for the financial assistance and the professor Dr. Daniel Pasquini of the Federal University of Uberlândia, MG, Brazil, for the infrastructure availability in order to obtain the cellulose nanocrystals.

\section{References}

Arnon, D. I. (1949). Copper enzymes in isolated chloroplasts: polyphenoloxidase in Beta vulgaris. Plant Physiology, 24(1), 1-15. http://dx.doi.org/10.1104/pp.24.1.1. PMid:16654194.

Arnon, H., Granit, R., Porat, R., \& Poverenov, E. (2015). Development of polysaccharides-based edible coatings for citrus fruits: a layerby-layer approach. Food Chemistry, 166(1), 465-472. http://dx.doi. org/10.1016/j.foodchem.2014.06.061. PMid:25053081.

Candido, R. G., \& Gonçalves, A. R. (2016). Synthesis of cellulose acetate and carboxymethylcellulose from sugarcane straw. Carbohydrate Polymers, 152(1), 679-686. http://dx.doi.org/10.1016/j.carbpol.2016.07.071. PMid:27516319.

Cazón, P., Velazquez, G., Ramírez, J. A., \& Vázquez, M. (2017). Polysaccharide-based films and coatings for food packaging: a review. Food Hydrocolloids, 68(1), 136-148. http://dx.doi.org/10.1016/j. foodhyd.2016.09.009.

Chen, C., Peng, X., Zeng, R., Wan, C., Chen, M., \& Chen, J. (2016). Physiological and biochemical responses in cold-stored citrus fruits to carboxymethyl cellulose coating containing ethanol extract of Impatiens balsamina L. Stems. Journal of Food Processing and Preservation, 41(1), 1-9. http://dx.doi.org/10.1111/jfpp.12999.

Dave, R. K., Ramana Rao, T. V., \& Nandane, A. S. (2017). Improvement of post-harvest quality of pear fruit with optimized composite edible coating formulations. Journal of Food Science and Technology, 54(12), 3917-3927. http://dx.doi.org/10.1007/s13197-017-2850-y. PMid:29085134.

Deng, Z., Jung, J., Simonsen, J., \& Zhao, Y. (2017). Cellulose nanomaterials emulsion coatings for controlling physiological activity, modifying surface morphology, and enhancing storability of postharvest bananas
(Musa acuminate). Food Chemistry, 232(1), 359-368. http://dx.doi. org/10.1016/j.foodchem.2017.04.028. PMid:28490085.

Dhital, R., Joshi, P., Becerra-Mora, N., Umagiliyage, A., Chai, T., Kohli, P., \& Choudhary, R. (2017). Integrity of edible nano-coatings and its effects on quality of strawberries subjected to simulated in-transit vibrations. Lebensmittel-Wissenschaft + Technologie, 80(1), 257-264. http://dx.doi.org/10.1016/j.lwt.2017.02.033.

Flauzino, W. P. No., Mariano, M., da Silva, I. S. V., Silvério, H. A., Putaux, J. L., Otaguro, H., Pasquini, D., \& Dufresne, A. (2016). Mechanical properties of natural rubber nanocomposites reinforced with high aspect ratio cellulose nanocrystals isolated from soy hulls. Carbohydrate Polymers, 153(1), 143-152. http://dx.doi.org/10.1016/j. carbpol.2016.07.073. PMid:27561481.

Gardesh, A. S. K., Badii, F., Hashemi, M., Ardakani, A. Y., Maftoonazad, N., \& Gorji, A. M. (2016). Effect of nanochitosan based coating on climacteric behavior and postharvest shelf-life extension of apple cv. Golab Kohanz. Lebensmittel-Wissenschaft + Technologie, 70(1), 33-40. http://dx.doi.org/10.1016/j.lwt.2016.02.002.

Jaramillo, C. M., Gutiérrez, T. J., Goyanes, S., Bernal, C., \& Famá, L. (2016). Biodegradability and plasticizing effect of yerba mate extract on cassava starch edible films. Carbohydrate Polymers, 151(20), 150 159. http://dx.doi.org/10.1016/j.carbpol.2016.05.025. PMid:27474554.

Kaewsuksaeng, S., Tatmala, N., Srilaong, V., \& Pongprasert, N. (2015). Postharvest Biology and Technology Postharvest heat treatment delays chlorophyll degradation and maintains quality in Thai lime (Citrus aurantifolia Swingle cv. Paan) fruit. Postharvest Biology and Technology, 100, 1-7. http://dx.doi.org/10.1016/j.postharvbio.2014.09.020.

Khorram, F., Ramezanian, A., \& Hosseini, S. M. H. (2017). Shellac, gelatin and Persian gum as alternative coating for orange fruit. Scientia Horticulturae, 225(1), 22-28. http://dx.doi.org/10.1016/j. scienta.2017.06.045.

Li, D., Li, L., Luo, Z., Lu, H., \& Yue, Y. (2017). Effect of nano-ZnOpackaging on chilling tolerance and pectin metabolism of peaches during cold storage. Scientia Horticulturae, 225(1), 128-133. http:// dx.doi.org/10.1016/j.scienta.2017.07.003.

Ma, L., Zhang, M., Bhandari, B., \& Gao, Z. (2017). Recent developments in novel shelf life extension technologies of fresh-cut fruits and vegetables. Trends in Food Science \& Technology, 64(1), 23-38. http:// dx.doi.org/10.1016/j.tifs.2017.03.005.

Mannozzi, C., Cecchini, J. P., Tylewicz, U., Siroli, L., Patrignani, F., Lanciotti, R., Rocculi, P., Dalla Rosa, M., \& Romani, S. (2017). Study on the efficacy of edible coatings on quality of blueberry fruits during shelf-life. Lebensmittel-Wissenschaft + Technologie, 85, 440-444. http://dx.doi.org/10.1016/j.lwt.2016.12.056.

Mditshwa, A., Magwaza, L. S., Tesfay, S. Z., \& Opara, U. L. (2017). Postharvest factors affecting vitamin $\mathrm{C}$ content of citrus fruits: a review. Scientia Horticulturae, 218(1), 95-104. http://dx.doi. org/10.1016/j.scienta.2017.02.024.

Nagalakshmaiah, M., kissi, N. E., Mortha, G., \& Dufresne, A. (2016). Structural investigation of cellulose nanocrystals extracted from chili leftover and their reinforcement in cariflex-IR rubber latex. Carbohydrate Polymers, 136(1), 945-954. http://dx.doi.org/10.1016/j. carbpol.2015.09.096. PMid:26572433.

Nawab, A., Alam, F., \& Hasnain, A. (2017). Mango kernel starch as a novel edible coating for enhancing shelf- life of tomato (Solanum lycopersicum) fruit. International Journal of Biological Macromolecules, 103(1), 581-586. http://dx.doi.org/10.1016/j.ijbiomac.2017.05.057. PMid:28522390.

Opio, P., Jitareerat, P., Pongprasert, N., Wongs-Aree, C., Suzuki, Y., \& Srilaong, V. (2017). Efficacy of hot water immersion on lime (Citrus auranifolia, Swingle cv. Paan) fruit packed with ethanol vapor in 
delaying chlorophyll catabolism. Scientia Horticulturae, 224(1), 258-264. http://dx.doi.org/10.1016/j.scienta.2017.06.034.

Oun, A. A., \& Rhim, J. W. (2016). Isolation of cellulose nanocrystals from grain straws and their use for the preparation of carboxymethyl cellulose-based nanocomposite films. Carbohydrate Polymers, 150(5), 187-200. http://dx.doi.org/10.1016/j.carbpol.2016.05.020. PMid:27312629.

Pelissari, F. M., Andrade-Mahecha, M. M., Sobral, P. J. A., \& Menegalli, F. C. (2017). Nanocomposites based on banana starch reinforced with cellulose nanofibers isolated from banana peels. Journal of Colloid and Interface Science, 505(1), 154-167. http://dx.doi.org/10.1016/j. jcis.2017.05.106. PMid:28577465.

Saberi, B., Golding, J. B., Marques, J. R., Pristijono, P., Chockchaisawasdee, S., Scarlett, C. J., \& Stathopoulos, C. E. (2018). Application of biocomposite edible coatings based on pea starch and guar gum on quality, storability and shelf life of 'Valencia' oranges. Postharvest Biology and Technology, 137(1), 9-20. http://dx.doi.org/10.1016/j. postharvbio.2017.11.003.
Segal, L., Creely, J. J., Martin, A. E. Jr., \& Conrad, C. M. (1959). An empirical method for estimating the degree of crystallinity of native cellulose using the X-ray diffractometer. Textile Research Journal, 29(10), 786-794. http://dx.doi.org/10.1177/004051755902901003.

Taiz, L., \& Zeiger, E. (2017). Plant physiology and development (6th ed.). Porto Alegre: Artmed.

Tibolla, H., Pelissari, F. M., Martins, J. T., Vicente, A. A., \& Menegalli, F. C. (2018). Cellulose nanofibers produced from banana peel by chemical and mechanical treatments: characterization and cytotoxicity assessment. Food Hydrocolloids, 75(1), 192-201. http:// dx.doi.org/10.1016/j.foodhyd.2017.08.027.

Xin, Y., Chen, F., Lai, S., \& Yang, H. (2017). Influence of chitosan-based coatings on the physicochemical properties and pectin nanostructure of Chinese cherry. Postharvest Biology and Technology, 133(1), 64-71. http://dx.doi.org/10.1016/j.postharvbio.2017.06.010.

Yousuf, B., Qadri, O. S., \& Srivastava, A. K. (2018). Recent developments in shelf-life extension of fresh-cut fruits and vegetables by application of different edible coatings: a review. Lebensmittel-Wissenschaft + Technologie, 89(1), 198-209. http://dx.doi.org/10.1016/j.lwt.2017.10.051. 